NBER WORKING PAPER SERIES

\title{
BAUMOL-TOBIN AND THE WELFARE COSTS OF NATIONAL SECURITY BORDER DELAYS
}

\author{
Hui Huang \\ John Whalley \\ Working Paper 12296 \\ http://www.nber.org/papers/w12296 \\ NATIONAL BUREAU OF ECONOMIC RESEARCH \\ 1050 Massachusetts Avenue \\ Cambridge, MA 02138 \\ June 2006
}

We are grateful to SSHRC for financial support. The views expressed herein are those of the author(s) and do not necessarily reflect the views of the National Bureau of Economic Research.

(O2006 by Hui Huang and John Whalley. All rights reserved. Short sections of text, not to exceed two paragraphs, may be quoted without explicit permission provided that full credit, including $\odot$ notice, is given to the source. 
Baumol-Tobin and the Welfare Costs of National Security Border Delays

Hui Huang and John Whalley

NBER Working Paper No. 12296

June 2006

JEL No. F1, F10, F13, F19

\begin{abstract}
The implications of national security related procedures for trade flows at border points in OECD countries has become a major topic of commentary in popular press. We discuss whether the economic costs of border delays are represented solely by time spent in awaiting processing. This has been the basis of calculations in Canada-US-Ontario (2004) and Ontario Chamber of Commerce $(2004,2005)$ of advalorem equivalent tariff representations of the time delays involved. While time can be a significant part of the social cost of security related delays in customs clearance, added costs also arise from the behavioral response to delays and looking only at the time delays at the border can be misleading. We use a formulation where border delays occur with certainty and add to the fixed costs of importing in any period. We develop analytics for the case where there is endogeneity both in the frequency of transactions and in the size of individual transactions across the border in the tradition of the well known Baumol (1952) and Tobin (1952) inventory theoretical analysis of the demand for money.
\end{abstract}

Hui Huang

School of Economics and Finance

Victoria University of Wellington

PO Box 600

Wellington

NEW ZEALAND

hui.huang@vuw.ac.nz

John Whalley

Department of Economics

Social Science Centre

University of Western Ontario

London, Ontario N6A 5C2

CANADA

and NBER

jwhalley@uwo.ca 


\title{
Baumol-Tobin and the Welfare Costs of National Security Border Delays*
}

\author{
Hui Huang \\ Victoria University of Wellington ${ }^{\dagger}$ \\ and \\ John Whalley \\ University of Western Ontario, CESifo and NBER ${ }^{\ddagger}$
}

March 14, 2006

\section{Introduction}

The implications of national security related procedures for trade flows at border points in OECD countries has become a major topic of commentary in popular press and government reports, but little or no academic research has addressed these issues. Here we explore whether the economic costs of border delays are represented solely by time spent in awaiting processing. This has been the basis of calculations in Canada-US-Ontario (2004) and Ontario Chamber of Commerce $(2004,2005)$ of advalorem equivalent tariff representations of the time delays involved. While time can be a significant part of the social cost of security related delays in customs clearance, added costs also arise from the behavioral response to delays and looking only at the time delays at the border can be misleading. Here we focus on added inventory holding which border delays can induce and argue both that the

*We am grateful to SSHRC for financial support

${ }^{\dagger}$ School of Economics and Finance, Victoria University of Wellington, PO Box 600, Wellington, New Zealand, E-mail: hui.huang@vuw.ac.nz

†DDepartment of Economics, The University of Western Ontario, Email: jwhalley@uwo.ca 
indirect behaviour induced costs of border delays can be substantial, and these costs do not follow a Hotelling-Harberger t-square rule as is true of conventional tariff distortionary costs.

We use a formulation where border delays occur with certainty and add to the fixed costs of importing in any period. We develop analytics for the case where there is endogeneity both in the frequency of transactions and in the size of individual transactions across the border in the tradition of the well known Baumol (1952) and Tobin (1952) inventory theoretical analysis of the demand for money. ${ }^{1}$ In related work Huang and Whalley (2006) also analyze cases where there is uncertainty over the arrival of an order and show that increased varience in delays can add to the costs involved even if the mean delay is unchanged.

In the case we consider the cost minimizing problem is to meet demand for an imported component over a number of periods, where importers have the option of importing smaller amounts each period and carrying little or no inventory, or importing less frequently and carrying more inventory. A fixed cost of importing each time due to border delays will reduce the frequency of importation, and result in the carrying of inventory. We consider two different cases, one where inventories depreciate (perish) and one where there is an interest financing cost to inventories generated by border delays. It is also possible to combine the two since analytically they are closely related.

Cudmore and Whalley (2003) is a recent paper motivated by delays in processing of imports in Russia and other CIS states analyze trade policy in a world with quantity constraints on imports due to processing constraints with endogenous queuing. They show that a tariff has the effect of reducing queuing and substitutes revenue racing for wasteful time use in queuing and can be beneficial as long as processing constraints bind. They highlight the feature that tariff liberalization without first removing administrative delays at borders can be welfare worsening. No other papers on border delays and their trade implications are known to us.

\footnotetext{
${ }^{1}$ The earlier formulation of optimal inventory control by Wilson (1934) and Harris (1915) is usually cited in management science literature as the origins of this form of analysis, but neither was seemingly known to either Tobin or Baumol. Baumol and Vimod (1979) later apply a similar inventory theoretic approach to choice of transportation mode.
} 


\section{The Impacts of Border Delays on Trade Flows and Inventory Holding}

We consider the case where the consumption of a good $X$ must meet a minimal requirement during a year and where the price of the good is fixed. For simplicity we assume we are dealing with the input of a good and the demand of a firm, but a similar analysis would hold for a final consumer demand good. The only source of supply is imports, and the issue is how much the firm buys each period. We assume that each period the firm has just enough money to meet the minimum requirement of the current period and if it wants to buy for more than this in the period it will need to borrow in order to pay for its purchases. If there were no transactions costs in the form of border delays, the firm would buy enough every period to meet the minimum requirement. If, however, there is a fixed cost of crossing the border once the good has been bought, the firm will want to minimize the costs of meeting demand in each period. The firm needs to pay interest on borrowed funds which finance inventory holding and choose the optimal number and size of transactions made at the border; effectively the frequency of purchase. This is similar in structure to the well known Baumol (1952) and Tobin (1956) inventory theoretic analysis of the demand for money.

More formally, the minimal requirement consumption of good $X$ during a year is $M$. We assume that the consumption occurs continuously during the year. The interest rate is $r$. The price of good $X$ is normalized to be 1 . The fixed time cost of transacting at the border each time a transaction occurs is $F$. Without border delays, the firm would buy $X$ continuously. With border delays, the firm reduces the number of transactions and carrys inventory.

If size each transaction by the firm is $C$, the average holding of inventory is $\frac{C}{2}$. The annual interest cost for these inventories will be $\frac{r C}{2}$. The time cost of border delays is $F \frac{M}{C}$

since $\frac{M}{C}$ is the number of transactions in the year. The total cost of meeting demand $M$ is thus

$$
\frac{r C}{2}+F \frac{M}{C}
$$

and the firm chooses a optimal $C^{*}$ so as to minimize this cost. 
Setting the derivative of $(1)$ with respect to $C$ equal to zero we obtain

$$
\frac{r}{2}-F \frac{M}{C^{2}}=0
$$

and the optimal choice of $C$ is

$$
C^{*}=\sqrt{\frac{2 F M}{r}}
$$

This is related to Baumol's (1952) formulation of the interest elasticity of the demand for money in a simple inventory theoretic model. In Baumol and Tobin, the demand for money reflect the fixed cost of visits to the bank and the interest opportunity cost of holding funds. In this formulation, the social cost of border delays are

$$
\frac{r}{2} \sqrt{\frac{2 F M}{r}}+F \frac{M}{\sqrt{\frac{2 F M}{r}}}=\sqrt{2 F M r}
$$

which exceeds the time delay $F \frac{M}{C}$, and by substitution in (2) can be shown to be double the time delay, i.e.

$$
F \frac{M}{C}=F \frac{M}{\sqrt{\frac{2 F M}{r}}}=\sqrt{\frac{F M r}{2}}
$$

An alternative and closely related formulation is where there are no interest costs of borrowing, but there is wastage or perishability of the good. Here, meeting a given demand involves trading off wastage costs against fixed costs in each period and as border delay costs increase the frequency of transaction will again fall. If we interpret $r$ as the wastage rate rather then the interest the same analytics apply.

Thus, in these formulations there is behavioural response to border delays in the form of reduced frequency of transactions of the border relative to a no border delay case, and the social costs of the border delay are given by the interest carrying costs of inventories and/or the wastage (perishing) of inventories in addition to the time costs. The size of these added costs will depend on parameter values including the interest rate and/or the rate of decay of goods.

\section{Concluding Remarks}

If we analyze the economic costs of national security related border delays in a BaumolTobin inventory theoretic framework where border delays represent a fixed cost at the 
border, and transactions may be spaced over a number of periods, the social costs of border delays are more than the time costs at the border. Behavioural response to the delays (in this case in the costs of added inventory holding) also have to be factored in. In related work (Huang and Whalley, 2006) we have also considered the case where there is uncertainty in the arrival time of orders due to border delays and the both mean and variance of arrival time can be affected. Here similar themes of results hold, but an increase in the variance of border delays (even if mean delays remain unchanged) can also impose substantial added costs.

\section{References}

[1] Baumol, William J., (1952), The Transactions Demand for Cash: An Inventory Theoretic Approach. Quarterly Journal of Economics, 66, 545-556.

[2] Baumol, W. J. and H. D. Vinod, (1970), An Inventory Theoretic Model of Freight Transport Demand. Management Science, 16(7), 413-421.

[3] Canada-US-Ontario-Michigan Border Transport Planning/Need Feasibility Study ("Bi-National Study"), (2004), Regional and National Impacts of Increasing Delay and Delay Related Costs at the Windsor-Detroit Crossing. http://partnershipborderstudy.com/pdf/Economic\%20Impact\%20Report_FINAL_29 Jan04WEB.pdf, last visited: February 14, 2006.

[4] Cudmore, Edgar, and John Whalley, (2003), Border Delays and Trade Liberalization, NBER Working Paper No. W9485.

[5] Harris, F.W. Operations Cost, Factory Management Series, Chicago: Shaw (1915).

[6] Huang, Hui, and John Whalley, (2006), The Costs of Uncertainty in Arrival Time of Orders Due to Border Delays, miemo.

[7] Ontario Chamber of Commerce, (2004), Cost of Border Delays to Ontario. http://occ.on.ca/2publications/reports/docs/CostofBorderDelaystoOntario_052004.pdf, last visited: February 14, 2006. 
[8] Ontario Chamber of Commerce, (2005), Cost of Border Delays to the United States Economy. http://occ.on.ca/2publications/reports/docs/CostofBorderDelaystoUS Economy_042005.pdf, last visited: February 14, 2006.

[9] Tobin, James, (1956), The Interest-Elasticity of Transactions Demand for Cash. Review of Economics and Statistics, 38, 241-247.

[10] Wilson, R.H. (1934) "A Scientific Routine for Stock Control", Harvard Business Review, 13, 116-128. 